\title{
Correction to: Increased Paracrine Immunomodulatory Potential of Mesenchymal Stromal Cells in Three-Dimensional Culture, by Follin B, Juhl M, Cohen S, Pedersen AE, Kastrup J, and Ekblond A. Tissue Eng Part B Reviews 2016;22(4):322-329. DOI: 10.1089/ten.teb.2015.0532
}

N THE August 2016 issue of Tissue Engineering, Part B (vol. 22, no. 4, pages 322-329), in the article entitled,
Increased Paracrine Immunomodulatory Potential of Mesenchymal Stromal Cells in Three-Dimensional Culture by
Bjarke Follin et al., the name of the fourth author was spelled incorrectly. The author's name was published in this article as:

"Anders Elm Perdersen"

The author's name should have appeared as:

"Anders Elm Pedersen"

The authors apologize for this error. 